\title{
2019 World of Shipping Portugal. An International Research Conference on Maritime Affairs editorial "Leading the shipping industry into the future"
}

\author{
Ana Cristina Paixão Casaca ${ }^{1,2^{*}}$ (D) and Maria Amélia Ramos Loja ${ }^{2,3,4}$
}

\begin{tabular}{l}
\hline *Correspondence: anaccasaca@ \\
sapo.pt \\
'World of Shipping Portugal, \\
Parede, Portugal \\
${ }^{2}$ CIMOSM, ISEL - Centro de \\
Investigação em Modelação e \\
Optimização de Sistemas \\
Multifuncionais (in English: \\
Multifunctional Systems Modelling \\
and Optimization Research Centre), \\
Instituto Politécnico de Lisboa, \\
1959-007 Lisboa, Portugal \\
Full list of author information is \\
available at the end of the article
\end{tabular}

available at the end of the article

\begin{abstract}
Background, the context and purpose of the study: The current Editorial addresses the evolutionary path of the shipping industry. It mentions its role throughout the years, identifies the leading market segments, refers to the different operational modes due to the inherent nature of the cargoes they carry and lists some trends that appear to have been shaping the maritime industry. Within the scope of this background, the Editorial claims that all maritime market segments face the same future challenges and lists a range of international legislation released by the International Maritime Organisation which industry players must comply with.
\end{abstract}

Findings, the main results: Not/aplicable.

Conclusions, brief summary and potential implications: The Editorial concludes by stating that the maritime industry will benefit from the implementation of innovative solutions and further claims that wrong decisions will have severe impacts on the finances of the shipping companies and the environment. Moreover, it presents in a brief way the papers published in this Special Issue, which were selected among the ones presented at the 2019 World of Shipping Portugal, an International Research Conference on Maritime Affairs, 21-22 November 2019, that took place at Hotel Riviera, in Carcavelos, Portugal.

Keywords: Maritime transport, Ports, Innovation management, Evolutionary path, Future of the industry

\section{Main text}

The evolutionary path under which the shipping industry has been going through is, without doubt, an amazing one. The discovery of the steam and its application onto the vessels of those times, where the steam replaced the sail, has, without doubt, removed the existing uncertainties derived from having good winds or not. It allowed the establishment of scheduled routes, which could be announced to shippers wherever they were located. Furthermore, the emerging undersea cable network, in the nineteenth century, linking the continents also transformed the shipping industry; until the 1860s international communications were carried by letter and little was known of a

(c) The Author(s). 2020 Open Access This article is licensed under a Creative Commons Attribution 4.0 International License, which permits use, sharing, adaptation, distribution and reproduction in any medium or format, as long as you give appropriate credit to the original author(s) and the source, provide a link to the Creative Commons licence, and indicate if changes were made. The images or other third party material in this article are included in the article's Creative Commons licence, unless indicated otherwise in a credit line to the material. If material is not included in the article's Creative Commons licence and your intended use is not permitted by statutory regulation or exceeds the permitted use, you will need to obtain permission directly from the copyright holder. To view a copy of this licence, visit http://creativecommons.org/licenses/by/4.0/. 
ship until she returned. Both events set the scene and sophisticated shipping systems, namely the liner and tramp shipping systems, emerged.

The liner shipping flourished, and trade agreements between remote regions of the world were established, thus pioneering the globalised environment in which we live today. The liner shipping industry, which so far lived in an environment of its own, has been forced to open its doors and extend its operations inland creating an array of integrated transport systems that link the north, the south, the east and the western boundaries of the planet. Moreover, it has been forced to adopt new business strategies, namely logistics and supply chain management strategies. The tramp market also evolved but kept its underlying principles of unscheduled voyages, which are still seen in the bulk markets. While they have different modes of operations because of the inherent nature of the cargoes they carry, they all face the same future challenges.

Today, the tanker, the dry bulk, and the container shipping markets dominate the world, where the latter shows a high level of innovation. Containerisation is one of the revolutionary innovations that changed the organisation in which the traditional liner shipping market operated. When Malcolm McLean shipped the first containers on board the converted tanker Ideal X in 1956, he was far from knowing the changes that such a box would bring to the world.

Going back into the market, several trends appear to have been shaping the maritime industry. First, the globalisation phenomenon has been having critical impacts at different levels. Seaborne trade volumes rose on average by 3\% per year from 1980 to 2013 to a level of 9.5 billion tons loaded, and in 2016, the entire transport volume of maritime trade amounted to approximately 11 billion metric tons. Also derived from the globalisation phenomenon is the emergence of integrated global supply chains to the extent that supply chain performance has become more important than the individual performance of its nodes as is the case of ports. Maritime transport is also becoming more integrated into multimodal transport chains to the extent that shippers/receivers determine by which port their cargo is conveyed to lower their inventories' associated costs.

Second, the market has been witnessing an increasing vessel size. Driven by the desire to cut transport costs, the industry has, as a whole, witnessed an increasing vessel size over the past 50 years, which was experienced initially in the tanker and dry bulk markets. Today increasing vessel size is more notorious in the container shipping market. The capacity of container ships in seaborne trade has risen significantly from 1980 through 2019. As of January 2018, there were 5152 container ships in the world's merchant fleet. In 2019, the world merchant container ship fleet had a capacity of around 266 million metric tons deadweight, the biggest containership, the MSC Gülsün, showed a maximum TEU capacity of 23,756 TEUs and according to Deloitte China, in 2017, the largest increase in average container ship size occurred on the Far East South Africa route. At the same time, vessel specialisation occurred to meet the different characteristics of the different types of cargoes being traded, and numerous types of vessels ply the ocean carrying them; some liquid other dry, some in bulk other in packaged form.

Third, the industry has been going through a series of structural changes. Some of these changes are more notorious in the container market where a select number of shipping companies dominate the market through mergers and acquisitions, takeovers and alliances. Fourth, the 2001 attack on the Twin Towers has been driving the 
industry into security issues, to the extent that the spending on security issues, both on international waters and in the port, has increased significantly since then. Fifth, more focus has been given to maritime logistics, in particularly multimodal transport and infrastructure. Ports have been at the forefront of adopting sophisticated ICT solutions to optimise their operations and the logistics chains in which they are integrated. More than ever, the port industry has been focusing on its hinterland, foreland, competition capacity and performance.

However, the constraints imposed by i) the climate change obliging vessels to comply with the global fuel sulphur limit of $0.5 \%$ which entered in force on 1 January 2020; ii) the IMO Ballast Water Management Convention, which has entered into force in September twenty seventeen (2017) as a means to stop non-native species from invading local marine environments and causing severe ecological, economic and public health impact on the receiving environment; iii) the International Convention on the Control of Harmful Anti-fouling Systems in Ships aimed at protecting the marine environment and human health from adverse effects of anti-fouling systems on ships by phasing out the use of harmful organotin compounds; iv) the need to improve effectiveness and efficiency of operations from economic, regulatory and safety point of views, and v) the Petya, a malicious software that has spread through large firms, and which shut down numerous Maersk operations, are driving the industry into the adoption of innovative solutions and the investment on research and development.

The point is that innovative solutions play a central role in making the maritime industry more efficient, cost-effective and compliant with rapidly evolving environmental rules. It is clear that future industry leaders will look for the best technologies available in the market, for instance, scrubbers versus LNG adoption. The challenge is to make the right investment since wrong decisions will have severe impacts on the finances of the shipping companies and the environment.

The current issue focus on innovative concepts applied to both the shipping and ports industry in order to improve their overall operational performance. (Kretschmann 2020) presents a framework in order to design maritime risk models based on safetyrelated data collected onboard ships. (Lim and Lim 2020) analyse the financial performance of shipping companies that support of eco-innovation through the acquisition of LNG carriers. (Vierth and Johansson 2020) perform a comparative analysis of two alternative systems for environmentally differentiated fairway dues in Sweden in order to provide input to develop further environmentally differentiated fairway dues. Finally, (Li et al. 2020) present the port business ecosystem evolutionary process by using an evolutionary game theory approach.

We thank Journal of Shipping and Trade for accepting this Special Issue and China Merchants Energy Shipping for supporting this Special Issue process charges.

Greetings from Lisbon.

Ana Cristina Paixão Casaca and Maria Amélia Ramos Loja.

Guest Editors.

Acknowledgements

We thank Journal of Shipping and Trade for accepting this Special Issue and China Merchants Energy Shipping for supporting this Special Issue process charges. 
Authors' contributions

AC contributed with the draft of the Editorial. The Editorial is based on the Opening Ceremony Speech delivered by Ana Cristina Paixão Casaca. ML revised and made the appropriate changes. All authors read and approved the final manuscript.

\section{Author's information}

Ana Cristina Paixão Casaca holds a PhD in International Transport/Logistics from the University of Wales - Cardiff. Her academic background is supported by her nautical career in the shipping industry. In 1985, she earned her elementary nautical studies degree at Escola Náutica Infante D. Henrique (ENIDH) in Paço D’Arcos, Portugal. She was a deck officer in Portuguese shipping companies and some years later taught at the Instituto de Tecnologias Náuticas, Portugal. In 1995, she earned her Bachelor Degree in Management and Maritime Technologies at ENIDH, and 2 years later, in 1997, she obtained her M.Sc. Degree in International Logistics at the Institute of Marine Studies, University of Plymouth, United Kingdom. In July 1998, she obtained her professional accreditation from the Institute of Chartered Shipbrokers, and successfully obtained her PhD in International Transport/Logistics in 2003. Between 1998 and 2007, she published several articles of a professional nature in Portuguese industry magazines. As from 2001 onwards, she focused on research and her work can be found in well-known international maritime-related journals. She organised in cooperation with Cargo Edições and chaired the 2010 Annual Conference of the International Association of Maritime Economists and the 2012 International Research Conference on Short Sea Shipping. In cooperation with Leo Tadeu Robles, she translated into Portuguese the third edition of the "Maritime Economics" book written by Martin Stopford. Since 2002, she has been invited to peer review academic papers submitted to well-known international Journals and participate as a member of several Conferences International Scientific Committees. Moreover, as from 2003 onwards, she has been invited by the European Commission as an External Expert in the field of maritime transport. She is the Founder and Owner of the 'World of Shipping Portugal' initiative which delivers Knowledge, Training and Translation Services within the scope of Maritime Economics. She is Associate Editor of Maritime Business Review, member of the Editorial Board of the Journal of International Logistics and Trade, member of the Institute of Chartered Shipbrokers (ICS), and the International Maritime Economists Association (IAME).

Maria Amélia Ramos Loja is presently Adjunct Professor at Mechanical Engineering Department of the Engineering Institute of Lisbon (ISEL, IPL) and Senior Researcher of the Mechanical Engineering Institute (IDMEC, IST). Her academic background integrates a BSC with honours in Marine Engineering from the Portuguese Nautical School and a BSc in Computer Science. Her MSc and PhD degrees in Mechanical Engineering were conferred by the Technical University of Lisbon and the Habilitation in Mechatronic Engineering by the University of Évora. Her major areas of interest include the scientific areas of Computational Solids Mechanics, Optimization and Reverse Engineering, among others. Until now she published more than 50 papers in international scientific journals. Amélia Loja is Chairperson of the ECCOMAS thematic series of conferences SYMCOMP (International Conference on Numerical and Symbolic Computation: Developments and Applications), and she coordinates the Research Centre on Modelling and Optimisation of Multifunctional Systems (CIMOSM, ISEL). Since 2017 she has been invited by the European Commission Research Agencies to evaluate project proposals in different subjects related to her competences.

\section{Funding}

Not Applicable.

\section{Availability of data and materials}

Not Applicable.

\section{Competing interests}

The Authors declare that they have no competing interests.

\section{Author details}

${ }^{1}$ World of Shipping Portugal, Parede, Portugal. ${ }^{2}$ CIMOSM, ISEL - Centro de Investigação em Modelação e Optimização de Sistemas Multifuncionais (in English: Multifunctional Systems Modelling and Optimization Research Centre), Instituto Politécnico de Lisboa, 1959-007 Lisboa, Portugal. ${ }^{3}$ IDMEC, IST -Instituto Superior Técnico, Universidade de Lisboa, 1049-001 Lisboa, Portugal. ${ }^{4}$ NOVA UNIDEMI, Universidade NOVA de Lisboa, Campus de Caparica, 2829-516 Caparica, Portugal.

Received: 11 February 2020 Accepted: 1 December 2020

Published online: 24 December 2020

\section{References}

Kretschmann, L. Leading indicators and maritime safety: predicting future risk with a machine learning approach. J. shipp. trd. 5, 19 (2020). https://doi.org/10.1186/s41072-020-00071-1

Li, W., Vanelslander, T., Liu, W. et al. Co-evolution of port business ecosystem based on evolutionary game theory. J. shipp. trd. 5, 20 (2020). https://doi.org/10.1186/s41072-020-00072-0

Lim, KG., Lim, M. Financial performance of shipping firms that increase LNG carriers and the support of eco-innovation. J. shipp. trd. 5, 23 (2020). https://doi.org/10.1186/s41072-020-00080-0

Vierth, I., Johansson, M. The impact of alternative environmentally differentiated fairway dues systems in Sweden. J. shipp. trd. 5, 25 (2020). https://doi.org/10.1186/s41072-020-00077-9

\section{Publisher's Note}

